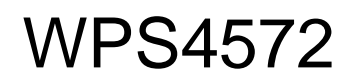

Policy Research Working Paper 4572

Post-Conflict Transitions Working No. 19

\title{
Partial Peace \\ Rebel Groups Inside and Outside Civil War Settlements
}

\author{
Desirée Nilsson
}

The World Bank

Development Research Group

Macroeconomics and Growth Team

March 2008 
Policy Research Working Paper 4572

\begin{abstract}
Previous research proposes that peace is more likely to become durable if all rebel groups are included in the settlement reached. The argument implies that if actors are excluded and continue to pursue the military course, this could have a destabilizing effect on the actors that have signed an agreement. This article argues that all-inclusive peace deals - signed by the government and all rebel groups - are not the panacea for peace that many seem to believe. Given that the parties are strategic actors who are forward-looking when making their decisions, the signatories should anticipate that the excluded parties may continue to fight. Therefore, the risk of violent challenges from outside actors is likely to
\end{abstract}

already be factored into the decision-making calculus when the signatories decide to reach a deal, and so does not affect their commitment to peace. Implications from this theoretical argument are tested using unique data on the conflict behavior of the government and each of the rebel groups in internal armed conflicts during the post-Cold War period. The results are well in line with the theoretical expectations and show that whether an agreement leaves out some actor does not affect whether the signatories stick to peace. The results demonstrate that even when excluded rebel groups engage in conflict, this does not affect the signatories' commitment to peace. Hence, the findings suggest that partial peace is possible.

This paper—a product of the Growth and the Macroeconomics Team, Development Research Group—is part of a larger effort in the department of a research project entitled Post-Conflict Transitions focusing on development issues particularly relevant to countries recovering from conflict. Policy Research Working Papers are also posted on the Web at http://econ. worldbank.org. The author may be contacted atdesiree.nilsson@pcr.uu.se@worldbank.org.

The Post-Conflict Transitions Working Paper Series disseminates the findings of work in progress to encourage the exchange of ideas about post-conflict development (more information about the Post-Conflict Transitions Project can be found at http:/lecon.worldbank.org/programs/ conflict). An objective of the series is to get the findings out quickly, even if the presentations are less than fully polished. The papers carry the names of the authors and should be cited accordingly. The findings, interpretations, and conclusions expressed in these papers are entirely those of the authors. They do not necessarily represent the views of the World Bank, its Executive Directors, or the countries they represent. Policy Research Working Papers are available online at http:/lecon.worldbank.org . 


\title{
Partial Peace Rebel Groups Inside and Outside Civil War Settlements*
}

\author{
Desirée Nilsson
}

Department of Peace and Conflict Research, Uppsala University

* I would like to thank Håvard Hegre, Gary Milhous, Ibrahim Elbadawi, and colleagues at the Department of Peace and Conflict Research, Uppsala University, in particular, Mats Hammarström, Margareta Sollenberg, Hanne Fjelde, Lisa Hultman, Isak Svensson, Anna Jarstad, and Erik Melander, for excellent comments and suggestions. The research was supported by the World Bank research project on 'Political Institutions, Development, and Domestic Civil Peace', funded by the Government of Norway. The replication data and a web appendix are available at http://www.prio.no/jpr/datasets. For recent versions of the UCDP data used here, see http://www.ucdp.uu.se. For correspondence: desiree.nilsson@pcr.uu.se. 


\section{Introduction}

A potential obstacle to durable peace, and an empirical reality of many civil wars, is that conflicts often involve numerous rebel groups. Cases in point are, for instance, Bosnia and Herzegovina, Burundi, Colombia, the Democratic Republic of Congo, and Sudan. Some scholars hold that if a peace agreement includes all the warring parties, peace is more likely to prevail (e.g. Hampson, 1996; Rubin, 2002). For instance, Licklider (2001: 701) stresses the importance of inclusiveness and points out that third parties ' ... should exert every effort to bring all of the important players into the process as soon as possible.' The argument implies that the presence of excluded parties can jeopardize peace, not only by heightening the risk of violence involving the outside actors, but also by influencing the commitment to peace among the signatories. However, while many seem to expect that all-inclusive peace agreements are more likely to see peace prevail, this claim has so far not been examined in a quantitative study. The present study addresses this lacuna in previous research by providing a first test of this proposition. Hence, the purpose of this article is to explore whether all-inclusive peace agreements are more likely to provide durable peace than partial agreements that leave out one or more rebel groups.

I argue that all-inclusive peace deals are not the panacea for peace that many seem to believe. If we think of parties in civil wars as strategic actors that look ahead when they make decisions, we can expect that the signatories have considered the possibility that excluded parties may continue to engage in armed conflict. Thus, the risk of violent challenges from outside actors is likely to already be factored into the decision-making calculus when the signatories decide to reach a deal. This suggests that while the excluded actors may continue to fight, settlements leaving out one or more rebel groups should not necessarily make the signatories any more likely to engage in violence.

Implications from this theoretical argument are tested using unique data from the Uppsala Conflict Data Program (UCDP) on the conflict behavior of the government and each of the rebel groups in internal armed conflicts, 1989-2004. The statistical analysis is conducted employing a Cox proportional hazards model. The results are well in line with the theoretical argument. The findings show that whether an agreement leaves out one or more rebel groups does not affect whether the signatories stick to peace. At the same time, agreements that exclude some party are found to reduce the overall prospects for peace in the conflict, that is, when taking 
into account the conflict behavior of both signatories and non-signatories. Moreover, the results demonstrate that outside actors are more likely to engage in post-settlement violence than the signatories. Importantly, the findings show that even if parties are excluded, and continue to fight, this is not affecting the signatories' commitment to peace. ${ }^{1}$ Hence, the results indicate that partial peace is possible.

\section{Previous Research}

The amount of scholarly work devoted to the issue of how to end conflicts and move towards durable peace has increased in recent years (e.g. Fortna, 2003, 2004; Hartzell \& Hoddie, 2003; Jarstad \& Nilsson, 2007; Walter, 1999, 2002b). However, while this field has seen significant advances, the literature on durable peace suffers from an unfortunate disconnect between the qualitative and quantitative research. Many case studies recognize that the rebel side often consists of several actors, and propose that various aspects such as spoiler dynamics can have implications for creating a lasting peace (e.g. Hampson, 1996; Stedman, 1997). Whereas case studies within the literature on durable peace emphasize that a refined view of the rebel side is needed, quantitative studies have, so far, mainly focused on two parties - the government and the opposition. ${ }^{2}$

In order to examine the question of whether to include all actors into peace agreements, as well as other pertinent issues, it is necessary to move beyond a characterization of civil war as involving only two parties. Indeed, by recognizing that civil wars often consist of multiple actors, we can begin to incorporate insights from case studies into our analyses of global patterns.

This article addresses the claim in the case study literature that in order to ensure durable peace, it is essential that all parties are included in the settlement. Indeed, a key hypothesis is that an inclusive agreement, in which all actors with the

\footnotetext{
${ }^{1}$ Note that the government may be a signatory to an agreement with one rebel group, and a non-signatory in relation to another rebel group. This means that even though the government in a strict sense is a signatory to one or more agreements, any conflict behavior between the government and an excluded rebel group is seen as violence involving non-signatories.

2 There are some studies that do incorporate some aspects pertaining to the rebel side, but these do not explore the dyadic interactions of the government and each rebel group, which forms a significant part of the present study (e.g. Doyle \& Sambanis, 2000; Fortna, 2003; Hoddie \& Hartzell, 2003).
} 
potential to resume hostilities take part, is more likely to provide a sustainable solution (Ohlson \& Söderberg, 2002). Hampson (1996: 217), for instance, argues that:

...it is absolutely essential that all the warring parties have a seat at the negotiation table and are directly involved in discussions about the new constitutional and political order that will be created after the fighting stops. A 'good' agreement is one that has been crafted by all parties to the conflict. If parties are excluded from these negotiations, or if their interests are not represented at the bargaining table, they will have a much stronger incentive to defect from the peace process and resort to violence to achieve their aims.

Licklider (2001: 701) also argues in favor of inclusive peace agreements and stresses that third parties should try to get all of the important players into the agreement and '...resist the temptation to settle for an easy agreement with moderates, (...) because such settlements are very likely to fail...' Moreover, according to Rubin (2002: 100), actors on the outside of an agreement may try to disrupt an agreement reached. He suggests that:

...one should probably attempt to include in negotiations all parties who are in a position to disrupt whatever settlement is arrived at; it may be more difficult to reach agreement with many parties and issues floating around, but if an agreement is reached under these circumstances, it will have a greater chance of surviving.

Consequently, an agreement that includes all parties to the conflict should be more likely to ensure that peace prevails than a deal where one or several parties are excluded. The mechanisms underlying the argument on inclusiveness are not clearly spelled out, but most of the works on this topic implies that excluded parties can threaten the peace between the signatories. In this context, the literature on spoilers in civil wars is relevant (Ayres, 2006; Newman \& Richmond, 2006; Stedman, 1997; Zahar, 2003). ${ }^{3}$ Indeed, the argument on inclusiveness seems to suggest that if an actor

\footnotetext{
${ }^{3}$ Stedman (1997: 5) defines spoilers as: '...leaders and parties who believe that peace emerging from negotiations threatens their power, worldview, and interests, and use violence to undermine attempts to achieve it.' Note that the present study treats all warring parties as potential spoilers, and hence, does not focus specifically on spoiler violence.
} 
on the outside continues to pursue the military course, this can have a destabilizing effect on the actors that have signed an agreement. ${ }^{4}$ Thus, according to previous research, an agreement that leaves out one or more parties should increase not only the risk that excluded parties engage in violent conflict, but also make the signatories more likely to fight.

\section{Signatories Sticking to Peace}

The claim that all parties should be included in a peace deal is appealing and seems to make intuitive sense. However, applying insights from bargaining theory, which emphasize the strategic nature of conflict, calls this into question. The bargaining perspective depicts war and its resolution as a bargaining process and at the center stage of analysis is the strategic interaction of the parties. The parties are seen to be acting strategically when '...each actor's ability to further its ends depends on how other actors behave, and therefore each actor must take the actions of others into account' (Lake \& Powell, 1999: 3). Scholars are increasingly arguing that parties in civil wars are to be seen as strategic actors who are forward-looking and try to anticipate the actions of other actors when making their decisions (e.g. Cetinyan, 2002; Walter, 2006). In this bargaining process between the warring parties revealing information plays a key role. By engaging in fighting and taking part in negotiations, the parties can reveal information about their reservation price (i.e. the minimum they can accept) and thus facilitate a settlement, instead of fighting a costly war. Whereas some actors may have revealed enough information about their capabilities and resolve in order to reach a bargain, the beliefs of others have not converged (i.e. they have different expectations about the outcome) and have yet to agree on a mutually preferable deal (Fearon, 1995; Filson \& Werner, 2002).

Applying these insights, I propose that all-inclusive peace agreements are not necessarily more likely to provide peace than a deal that leaves out some actor. The argument in previous research suggests that settlements that do not include all parties increase the risk that the signatories engage in conflict, primarily as a consequence of violence from the excluded parties. But if we consider that the warring parties are

\footnotetext{
${ }^{4}$ While not explicitly stated in the literature, it is conceivable that the signatories are influenced not only by direct spoiler attacks intended to wreck the peace, but it may also, for various reasons, be more difficult for the signatories to stick to peace if the non-signatories continue to pursue their war.
} 
strategic actors that try to anticipate the decisions of all other actors, this yields other expectations. I argue that the signatories, when taking the decision to sign a deal, are trying to anticipate the actions of all actors in the conflict, including rebel groups outside of the peace agreement.

The warring parties that decide to sign an agreement know if there are excluded parties, and presumably they have considered the possibility that the actors on the outside may continue to fight. The fact that the government and the excluded parties are unable to reach a deal suggests that they do not share the same expectation concerning the likely outcome on the battlefield, and hence, will continue to pursue the military course. Still, some parties may have the same expectations about the outcome without necessarily signing an agreement, and it is also conceivable that an excluded group may have been marginalized due to its insignificance, or may be weakened as the government redirects its forces against parties outside of an agreement. This could, hence, make violence involving outside actors less likely. However, on average, it is more plausible to expect that excluded parties will engage in violence.

This is not to say that the signatories in civil war are able to anticipate every move by the outside actors. In some instances the signatories may for some reason expect that the non-signatories will refrain from using violence. But since excluded actors in general are likely to fight, it is probably more common that the signatories expect that outside actors will engage in conflict. Moreover, the argument is not implying that signatories always stick to peace, while the non-signatories do not. Certainly, some signatories may have signed an agreement without having benign intentions, and even if the signatories do intend to stick to peace, commitment problems may serve to increase the risk of violence. ${ }^{5}$ This said, the non-signatories should probably be more likely to engage in violence following a settlement than the signatories. Hence, the signatories should have a fairly good sense of the violent challenges they may be facing, and therefore, take such a scenario into account when signing the deal.

\footnotetext{
${ }^{5}$ A credible commitment problem can arise when the parties agree on the bargaining range and would like to avoid the costs of war, but fear that the other party may renege on the deal. See, for instance, Walter (2002b).
} 
The fact that this argument calls into question the necessity of all-inclusive deals may at first glance seem discouraging. However, the argument rather implies that there may be many different paths to peace, since the signatories are expected to commit to peace, even if some party is left on the outside. Hence, agreements that exclude some actors may be one way forward when an all-inclusive deal is not possible.

There are several testable implications that follow from my theoretical argument. To begin with, focusing on the settlement as such, it is possible to draw out two implications. First, whether a peace agreement is all-inclusive or not, is not likely to affect the signatory peace (i.e. whether peace prevails in terms of all the signatories sticking to peace). The second implication is that since the excluded parties are likely to continue to fight, an agreement that leaves out one or more rebel groups should reduce the overall prospects for peace (i.e., whether peace prevails in the entire conflict taking into account the conflict behavior of both signatories and nonsignatories). In other words, if the agreement fails to include some rebel group, this should not affect whether the signatories stick to peace, but is likely to reduce the overall prospects for peace since the non-signatories may engage in conflict.

Furthermore, if we move the analysis to the dyadic interactions between the government and each of the rebel groups, there are some additional implications. The third implication is that the non-signatories, on average, should be more likely to engage in post-settlement violence than the signatories. Fourth, focusing specifically on the signatory dyads, the argument suggests that each of these should not be any more likely to resort to violence if the deal excludes some actor. The fifth and last implication takes this notion of exclusion one step further. Even if the signatories are faced with excluded parties that engage in conflict, we should not expect to see an increase in the risk of signatory violence. By examining these implications from my theoretical argument this article aims to shed light on the issue of whether allinclusive peace agreements can affect the prospects for peace.

\section{Research Design}

\section{Data}

The data are from the Uppsala Conflict Data Program (UCDP) and include all internal armed conflicts where at least one peace agreement has been signed during the period 
1989-2004. ${ }^{6}$ The UCDP defines an internal armed conflict as a contested incompatibility over government and/or territory, between a government and an opposition organization, and which reaches the level of minor armed conflict, that is, at least 25 battle-related deaths in at least one year. The UCDP dataset covering the post-Cold War period is unique in that it includes yearly data on all rebel groups involved in an armed conflict with the government that has reached at least this level of battle-deaths. For the purposes of this study, it is necessary to have comparable yearly data on the conflict behavior involving the government and each of the rebel groups. Hence, this dataset will be used.

Each internal armed conflict consists of one or more dyads, where the government and each rebel group engage in violence reaching the level of 25 battlerelated deaths in at least one year. Hence, there may be two or more warring parties, of which one is always the government. In this study a party that prior to the peace agreement met the criterion of 'warring party' is of interest, and the government and these rebel groups may, or may not, have signed a peace agreement in the conflict. The reason for focusing on the warring parties is that these have been active in the conflict and at some point had both the incentives and capabilities to use armed violence.

The UCDP also provides a comprehensive dataset of all peace agreements signed in the post-1989 period. Some other lists of peace agreements only focus on the settlements signed by all, or the major warring parties (e.g. Walter, 1999: 127128, 2002b: 52). For the purposes of this study, it is necessary to include all peace agreements and not merely those signed by certain rebel groups. The dataset from the UCDP includes agreements where only some of the rebel groups are signatories. Hence, this study covers all peace agreements that are signed by the government and one or several rebel groups, and which address the incompatibility by settling all or part of it (UCDP, 2006). ${ }^{7}$ The data used consists in total of 82 peace agreements in 40 internal armed conflicts, and some of the conflicts stand out in terms of the number of

\footnotetext{
${ }^{6}$ If not otherwise mentioned, the data in this study comes from the UCDP. For definitions of concepts, see UCDP (2006) and Harbom, Högbladh \& Wallensteen (2006). Note that since the conflict behavior of the parties is assessed the year after the signing of a peace agreement, and this data has been available up till 2004, only agreements up till 2003 are included in the study.

${ }^{7}$ In line with previous research I do not study 'peace process agreements' since these are merely 'outlining a process for regulating or resolving the incompatibility' (Sollenberg, 2002: 14).
} 
agreements signed: for example, in Chad nine peace agreements were reached in the period under study. Other conflicts, such as the one in Congo-Brazzaville, have only seen one peace agreement during the same period.

\section{Statistical Technique and Structure of the Datasets}

The empirical evaluations are conducted using duration analysis. In this case the interest lies in the duration of peace after the signing of a peace agreement, up to the point where the warring parties may engage in post-settlement armed conflict (i.e. experience an event), if at all. I use a Cox proportional hazards model which has the advantage of not assuming a specific parametric form for its distribution (Cox, 1972).

In an effort to evaluate the issue of inclusiveness as thoroughly as possible, two different datasets have been constructed, one focusing on the settlement level, whereas the other shifts the focus to the dyadic interactions between the government and each rebel group. When analyzing the settlement level, the unit of analysis is the post-agreement-year, whereas the analysis at the dyadic level concerns the government and each rebel group, and the unit of analysis is the post-agreement-dyadyear. In the dyadic dataset there may be several dyads in a conflict, where the government remains the same in each dyad.

In both datasets the peace agreements and dyads, respectively, are at risk of experiencing an event - that is, armed conflict involving a government and a rebel group that results in at least 25 battle-related deaths in a year - from the year after the signing of an agreement, until the observation period ends on the $31^{\text {st }}$ of December $2004 .^{8}$ The first dataset consists of 82 peace agreements, and in the dyadic dataset there are in total 84 dyads, which may or may not have signed one or more settlements. Since some of the variables vary over time, models with time-varying covariates are used for both sets of data, which makes it possible to study changes over time. This means that there are multiple observations for each of the settlements and dyads, respectively.

In the dyadic dataset, the dyads run the risk of experiencing post-settlement armed conflict after each of the agreements (if there are several signed in the

\footnotetext{
8 The primary focus is on the parties that were active prior to the signing of the agreement, and therefore new parties that later emerge are not taken into account in the main analysis. However, in the analysis at the settlement level a robustness check is conducted using an alternative dependent variable that captures the conflict behavior of new parties too.
} 
conflict). ${ }^{9}$ Thus, in this dataset, the dyads may exit the risk set if they experience armed conflict following a settlement, and then reenter on the condition that a new settlement is reached. Note that whenever a settlement is reached by any of the rebel groups in the conflict, the settlement becomes analytically relevant for all dyads in the conflict, regardless of whether these are signatories or not. Some of the dyads may engage in post-settlement violence more than once. For example, in the conflict between the Israelis and the Palestinians, several peace agreements have been signed, and the non-signatory Hamas have engaged in violence with the Israeli government following more than one of these agreements. Hence, I employ a duration model that can handle such repeated events. ${ }^{10}$

\section{Dependent Variables}

The post-settlement period is often more complex than peace simply prevailing or breaking down, therefore it is important that our dependent variables reflect what a durable peace may entail. Given that the signatories as well as the non-signatories may use violence after an agreement has been signed, it is important to take into account both these dimensions of peace duration. ${ }^{11}$ Since the unit of analysis is different for the two sets of data, the dependent variables used for the settlement and dyadic level are not the same.

In the analysis at the settlement level, two dependent variables are employed in order to capture different dimensions of peace duration, that is, the signatories' commitment to peace, but also the overall peace duration in the conflict. The variable Signatory Peace Duration measures the number of years of peace from the signing of the agreement until the government and at least one of the other signatories engage in

\footnotetext{
${ }_{9}^{9}$ Some dyads drop out of the data earlier either because the incompatibility is resolved or due to the fact that they cease to exist. For instance, if a rebel group completely dissolves or takes over the government the dyad drops out of the dataset. Based on information in the Uppsala Conflict Database, each of the parties in the dataset was evaluated according to these criteria in order to determine whether the dyad should continue to remain under observation or not (UCDP, 2006).

${ }^{10}$ More specifically, I use a conditional gap time model, see Box-Steffensmeier \& Jones (2004: 159-161).

${ }^{11}$ It can be the government as well as any of the rebel groups that is the first to return to armed conflict after an agreement. While this is an interesting aspect to consider, the data used here does not make it possible to determine which actor that first resorts to violence.
} 
violence, or, if peace has prevailed, to the end of the observation period. ${ }^{12}$ Hence, this variable focuses on the behavior of the signatories to the agreement. To exemplify, in Colombia, the peace agreement signed between the government and EPL in 1991, was not followed by armed conflict between the signatories until years later when, in 2004, the fighting between the government and EPL again reached the level of minor armed conflict. ${ }^{13}$ Meanwhile, FARC-EP and ELN, who did not sign the peace agreement, continued to fight. But since this variable is intended to only capture the conflict behavior of the signatories, this means that in terms of the signatory peace duration, peace prevailed for 13 years.

In contrast, the variable Overall Peace Duration, takes into account the conflict behavior of the government, the other signatories to the agreement, as well as the non-signatories, that is, the warring parties that were standing outside of the deal. This variable is measured as the number of years of peace from the signing of the agreement until either a signatory or a non-signatory becomes involved in armed conflict, or if peace has prevailed, to the end of the observation period. Again, taking the example of Colombia, the fact that the government and the FARC-EP and ELN continued to fight is captured by this variable. Thus, whereas peace prevailed in Colombia for 13 years in terms of the signatory peace duration, the overall peace duration broke down immediately, as the non-signatories FARC-EP and ELN continued their struggle.

In the analysis at the dyadic level, the dependent variable measures the conflict behavior of the government and a particular rebel group. The variable Dyadic Peace Duration captures whether the dyad, consisting of a government and a rebel group, was engaged in armed conflict from the signing of a settlement in the conflict, till the end of the observation period. Thus, in this case, the conflict behavior is measured for each dyad, and the rebel group may, or may not, be a signatory to a settlement. In Colombia, the dyad consisting of the government and EPL is at peace until 2004, whereas the dyads involving the government and FARC-EP and ELN, respectively,

\footnotetext{
12 Occasionally, there are several peace agreements reached in the same conflict. Of these, there are a few in which the signatories to the settlement already are at peace when they decide to reach another peace agreement. To avoid overestimating the impact that these agreements may have on peace duration, the subsequent agreement is seen as replacing the previous one.

${ }^{13}$ Some minor incidents are reported at various occasions during this period, but the violence concerning EPL does not in any given year reach 25 battle-related deaths until it does so in 2004.
} 
continued to fight and therefore experienced post-settlement armed conflict already the first time of observation, that is, the year following the agreement in 1991.

In both datasets, the post-settlement armed conflict is measured as of the year following the peace agreement to ascertain that the violence has taken place after the settlement was signed. While it would have been preferable to measure the dependent variable directly after the signing of a settlement, the fact that it is the yearly accumulation of at least 25 battle-related deaths which is studied makes such an approach unfeasible. $^{14}$

\section{Independent Variables}

A key aspect is the rebel groups' inclusion or exclusion in relation to a particular peace agreement. The first variable Exclusive-Multiple, which is used at the settlement level, is coded 1 if one or more rebel groups are standing on the outside of the deal, and is coded 0 otherwise. In order to account for the fact that two-party conflicts are all-inclusive by definition, this variable will be used together with the variable Two-Party Conflict, coded 1 if the conflict involves only two parties, and is coded 0 if the conflict involves three or more actors. By using these variables in the same model it becomes possible to assess the effect of partial agreements versus allinclusive agreements in a multiparty context.

In the analysis at the dyadic level, the variable Excluded refers to a particular rebel group's inclusion or exclusion in relation to a settlement. The variable is coded 1 if the rebel group, in a given year, had not signed a peace agreement, and is coded 0 if the rebel group had signed a peace agreement, or previously signed a peace agreement and then refrained from using violence. ${ }^{15}$ In a sub-sample of the dyadic dataset covering all the signatories two other variables concerning exclusion are used. The first variable Exclusive-Peace Agreement is coded 1 if the dyad was a signatory to a deal that excluded some actor, and is otherwise coded 0 . The second variable

\footnotetext{
14 The lowest peace duration is therefore one year, although a dyad may engage in conflict immediately after a settlement.

15 This means that a group that has signed an agreement and then resorted to violence is considered to be a potential signatory to any subsequent peace agreement signed in the incompatibility. Thus, if another peace agreement is signed in the incompatibility and they remain on the outside of the deal, such a group is seen as excluded. Conversely, if a rebel group has signed an agreement and then refrained from using violence during the observation period, it is coded as included in any subsequent agreement.
} 
Excluded-Fight is coded 1 if there is one or more excluded parties that in a given year engages in conflict with the government, and if not, this variable is coded 0 .

The control variables in this study include such factors which previous research have argued to influence peace duration, and theoretically may affect the independent variables as well as the dependent variables. The control variables are basically the same for both levels of analysis, and where there is a difference this is pointed out. To begin with, it is essential to control for the number of parties in each conflict as this potentially can affect the results. The variable Number of Parties measures the number of warring parties that has been active in the conflict from 1989 and onwards, up until the year in question.

Although the findings are contradictory, previous research has indicated that the conflict duration increases the duration of peace, while the intensity of the conflict has been suggested to decrease peace duration (e.g. Doyle \& Sambanis, 2000: 787; Fortna, 2004; Hartzell, Hoddie \& Rothchild, 2001: 202). In the dataset at the settlement level, the variable Conflict Duration counts the number of years since the conflict first reached the threshold of 25 battle-related deaths (which may be before 1989), up to a given year. In the dyadic dataset, I control for Dyad-Conflict Duration, which is measured in the same way but starts counting from the year when a particular dyad first reached this threshold. Furthermore, the variable Conflict Intensity is used at the settlement level and is coded 1 if the conflict (either in the year of observation or previously) reaches the level of war, meaning more than 1000 battle-related deaths in a year, and is otherwise coded 0 . In the dataset at the dyadic level, I include the variable Dyad-Conflict Intensity which is coded in the same fashion as conflict intensity, but this variable instead captures whether a particular dyad has reached the level of war or not. Moreover, whether the conflict concerns a certain territory or power over the government can possibly affect the prospects for peace (e.g. Wallensteen, 2002; Zartman, 1995). Thus, I created a control variable Conflict Issue which is coded 1 if the incompatibility is fought over government and 0 if it is fought over territory (UCDP, 2006).

Peacekeeping forces have been found to play a key role in the post-settlement phase by increasing the duration of peace (Fortna, 2003). In addition, it has been proposed that UN peacekeepers may be more 'neutral' than regional peacekeepers (Zahar, 2003: 117). Hence, I control for UN Peacekeeping, which is coded 1 if a peacekeeping operation led by the United Nations was present in a given year, 0 
otherwise. I also control for Non-UN Peacekeeping, in order to capture whether other peacekeeping forces than the UN were deployed. This variable is coded similarly to the UN Peacekeeping variable. For a description of the data used, see Heldt \& Wallensteen (2006). Finally, in line with previous research I control for the type of deal reached, since agreements with power sharing provisions could be more likely to see peace endure (Hartzell \& Hoddie, 2003). Hence, the dummy variable Power Sharing was coded 1 if the agreement contained at least one pact concerning the sharing of power, that is, military, territorial or political power, and was otherwise coded $0 .^{16}$

\section{Results and Analysis}

From my theoretical argument it was possible to derive five testable implications, and the results from the statistical analysis are presented in Table I and II. ${ }^{17}$ In all models, the hazard ratios are reported rather than the coefficients. A hazard ratio above one increases the risk of post-settlement violence, whereas a value below one decreases the risk of post-settlement violence. To exemplify, a hazard ratio of 1.5 means that the risk of peace failing is increased by $50 \%$, and a hazard ratio of 0.7 indicates that the risk of peace failing is decreased by $30 \%{ }^{18}$

I begin by examining the implications at the settlement level, and the first implication is assessed by looking at the peace duration for the signatories (Signatory Peace Duration). The first expectation that was derived from my argument proposes that whether a peace agreement is all-inclusive or not, should not affect the signatories' commitment to peace. The variable Exclusive-Multiple shows the effect of an agreement that leaves out one or more actors versus a deal that includes all actors, in a multiparty context. The results indicate no statistically significant effect of the variable Exclusive-Multiple on the duration of peace for the signatories (Model 1, Table I). Hence, the result is in line with the theoretical argument that the signatories should have considered that the excluded parties might threaten the peace process, therefore not affecting the signatories' commitment to peace. The effect even goes in the opposite direction to previous research, which has suggested that all-inclusive

\footnotetext{
16 This is coded in line with the definitions in Walter's (2002a) war termination dataset (Nilsson, Svensson \& Sundberg, 2006).

${ }^{17}$ For descriptive statistics, see the web appendix.

18 All statistical analyses are carried out using Stata 10.0 (StataCorp, 2007).
} 
deals increase the prospects for peace. Indeed, if anything, the findings rather indicate that all-inclusive agreements make the signatories more likely to fight. ${ }^{19}$ To see whether it may be sufficient that most, rather than all of the actors, have signed the deal, I estimated a model that includes a variable that captures the proportion between the number of signatories and the number of warring parties to a conflict. But no significant effect could be found.

The second implication focuses on the overall peace, taking into account the conflict behavior of both signatories and non-signatories (Overall Peace Duration). The expectation is that an agreement leaving out one or more rebel groups should reduce the overall prospects for peace, since the excluded parties are likely to continue to fight. As can be seen in Model 2, Table I, the variable Exclusive-Multiple has a statistically significant effect at the 0.05 level concerning the overall peace duration, that is, when taking into account the conflict behavior of the signatories, as well as the non-signatories. ${ }^{20}$ Hence, the result is in the expected direction, and shows that if an agreement excludes one or more rebel groups, the risk of post-settlement violence involving either signatories or non-signatories increases by $84 \%$. Given that no such effect could be found when studying the conflict behavior of the signatories suggests that the prospects of overall peace are reduced, due to violence involving the non-signatories. ${ }^{21}$ The results at the settlement level, however, only give us the general picture, and there is hence a need for a more fine-grained analysis focusing on the interactions between the government and the different rebel groups.

[Table I in here]

\footnotetext{
19 One possible interpretation is that some actors that sign an all-inclusive agreement have done so due to outside pressure from a third party, and therefore signatories to such a deal may be more likely to resort to armed conflict (e.g. Werner \& Yuen, 2005).

${ }^{20}$ It can be noted that in an alternative specification, using a linear measure of the number of parties, exclusion is no longer significant but is still in the expected direction. This alternative model, however, cannot at the same time account for the fact that agreements in two-party conflicts are all-inclusive by definition, which is an important aspect to consider.

${ }^{21}$ This is also in line with the expectation in previous research that all-inclusive deals may increase the prospects for peace, but notably such an effect cannot be found when only looking at the signatories.
} 
In the analysis at the dyadic level the focus is on the duration of peace for the government and each of the rebel groups (Dyadic Peace Duration). ${ }^{22}$ The third expectation based on my argument stated that given the signing of a settlement in a conflict, on average, the non-signatories should be more likely to engage in postsettlement violence than the signatories. The findings support this expectation, as the variable Excluded shows an increase in the risk that a dyad will engage in violence (Model 1, Table II). ${ }^{23}$ If a rebel group is a non-signatory rather than a signatory, the risk of post-settlement armed conflict doubles, and the result is statistically significant at the 0.01 level. Put differently, if a rebel group has signed an agreement, such a group is more likely to see peace prevail compared to a rebel group on the outside of the deal. This is notable, since the results at the settlement level indicate that an allinclusive-agreement does not make the signatories any more likely to stick to peace. The results here at the dyadic level thus add an important piece of information, by showing that it does make a difference whether the parties sign settlements or not.

\section{[Table II in here]}

In an effort to probe deeper into the mechanisms, I explore if the exclusion of parties is affecting the signatories' commitment to peace. Given that the fourth and fifth implications focus specifically on the signatories, the analysis is carried out on a sub-sample that consists of the signatory dyads. The fourth implication suggests that the signatories should not be any more likely to resort to violence if a deal excludes some of the parties. This is evaluated in Model 2, Table II, and the variable ExclusivePeace Agreement, shows no statistically significant effect on the risk of the signatories engaging in post-settlement armed conflict. This is in line with the argument, as the signatories should have taken into account whether some actor was

\footnotetext{
22 The models at the dyadic level have also been conducted on a sub-sample of the conflicts with multiple actors (since two-party conflicts are all-inclusive by definition), but the results remain the same.

${ }^{23}$ Since it is very rare that excluded parties are given anything in the peace agreement, I did not find it suitable to include the variable Power Sharing in this model. It can be noted that when doing so the variable Excluded is no longer statistically significant but still in the expected direction. I propose that the variable Power Sharing is best thought of as an intervening variable that may explain why some signatories stick to peace and others not.
} 
excluded from the agreement, and hence, it should not affect the signatories' commitment to peace.

The fifth and last implication takes this notion of exclusion one step further. Even if the signatories are faced with excluded parties that engage in conflict, we should not expect to see an increase in the risk of signatory violence. The variable Excluded-Fight, which captures whether there is one or more excluded groups that are engaged in conflict with the government, shows no statistically significant effect on the risk of signatories resorting to violence (Model 3, Table II). Hence, also this finding is in line with the argument put forward. While the peace process might be considerably more difficult if there are violent challenges to a peace deal, the results suggest that the exclusion of parties as such only makes outside actors more likely to engage in violence, and without necessarily increasing the risk that the signatory peace will fail.

Taken together, the findings from evaluating the five implications are well in line with the theoretical argument suggesting that a deal that excludes some actor does not necessarily increase the risk that the signatories will engage in post-settlement violence. Indeed, a closer look at the data shows that there are several cases where the signatories stick to peace even when another warring party is left on the outside of the agreement. For example, the Philippine government in 1996 reached a settlement with the MNLF, and peace has prevailed in spite of continued violence involving the Abu Sayyaf, as well as the MILF. ${ }^{24}$ Similarly, in Burundi, the signatories to the agreement reached in 2000, namely Frolina, Palipehutu and CNDD, did not return to armed warfare in spite of the fact that CNDD-FDD and Palipehutu-FNL continued to fight. Notably, in both conflicts the outside actors continued to fight, while the signatories remained committed to peace.

Hence, partial peace agreements may be one possible path to peace. This is not to suggest that partial agreements necessarily are better than all-inclusive deals, indeed, the results show that excluded parties often continue to fight. This said, if some deals never are materialized because it is too difficult to get all parties to agree, then a partial agreement could be an attractive option. After all, a deal that excludes

\footnotetext{
${ }^{24}$ It should be noted that armed conflict also came to involve the MNLF faction that emerged, whereas MNFL can be seen to have remained committed to peace.
} 
some actor may be successful in terms of getting the signatories to stop fighting. ${ }^{25}$ In order to ascertain whether a partial agreement is better than no agreement at all, it would be preferable to study all conflicts (i.e. also those conflicts where no settlement has been reached), and compare the conflict behavior of the signatories to that of all non-signatories. ${ }^{26}$ However, this lies outside the scope of this study. What can be done is to look at the duration of peace in substantive terms by comparing the signatories with the non-signatories in this particular sample. Using the program Clarify, the expected duration of peace for signatories and non-signatories is estimated, holding all other variables at their median values (Tomz, Wittenberg \& King, 2001). ${ }^{27}$ The result shows that the difference in peace duration is quite substantial, in particular considering that the study only covers the post-Cold War period. The expected peace duration for a rebel group that has signed an agreement is approximately eight years, whereas the corresponding figure for a non-signatory is only about two years. In other words, being a signatory instead of a non-signatory adds another six years of peace. ${ }^{28}$ The findings here thus indicate that the signing of an agreement makes a substantial difference for peace.

The results were obtained while controlling for a number of factors, and some of these are shown to significantly affect the risk that peace fails following a settlement. The models focus on different dimensions of peace, and hence, it is not surprising that the results are not the same across all models. I will briefly present a few of the most notable findings. The results on the settlement level show that the

\footnotetext{
${ }_{25}$ Occasionally the signatories stop fighting already some time before the agreement is signed. This could lead one to suspect that the decision to stop fighting led to the signing of the settlement, and not the other way around. However, even if a group stops fighting before the signing of a deal, they may have done so in the anticipation of a future deal. The fact that the government agrees to sign an agreement and thereby granting concessions suggests that they continue to pose a military treat.

${ }^{26}$ For instance, there might be some kind of selection effect taking place. This is, however, only a problem if there is some underlying factor that explains both why parties sign agreements and why they stick to peace.

27 Note that Clarify cannot be used with a Cox model and does not allow for stratification. Instead, I employed a Weibull model without stratification, and the expected values should be seen as indicative only. Moreover, since peace duration is measured one year after the agreement, I have subtracted one year from the values given by Clarify.

${ }^{28}$ Looking only at the partial agreements, the expected peace duration is six years for the signatories, compared to only one and a half year for the non-signatories, hence, there is still a substantive difference.
} 
intensity of the conflict is found to significantly affect the risk that peace fails. This is in line with previous findings showing that particularly deadly wars are more likely to see the conflict resume (Fortna, 2003). Furthermore, if agreements include some form of power sharing, there is an increased chance of peace prevailing, which is in accordance with previous research (Hartzell \& Hoddie, 2003). It can also be noted that, at the dyadic level it is found that the risk that a dyad will engage in conflict increases if the conflict is fought over government rather than territory. Finally, concerning the role of third parties, the findings at the dyadic level indicate that the non-UN peacekeeping forces are not very encouraging in terms of creating conditions for durable peace.

In addition to controlling for these factors identified in previous research, a number of alternative specifications and statistical tests were carried out. ${ }^{29}$ To ascertain that no particular case is driving the results, I have identified outliers using deviance residuals, and re-estimated the models without the outliers, but the results remain the same. Moreover, a potentially influential case is Chad, where many partial agreements have been signed, thus, as a robustness check I include a dummy variable for this conflict, but this does not affect the results. Furthermore, in the models at the dyadic level, I tried some alternative measures of the variable Number of Parties, but the results hold also when using a dummy, capturing whether it was multiparty conflict or not, and when adding a square term of the linear measure in order to explore curvilinear effects. Moreover, the results remain the same when controlling for the type of political system and the level of economic development measured in

\footnotetext{
${ }^{29}$ I test the assumption that the hazard is proportional by performing tests based on the scaled Schoenfeld residuals, and both covariate-specific and global tests are carried out. Some of the global and covariatespecific tests indicated violations of the assumption concerning the models at the dyadic level. To deal with this issue, I have interacted one of the violated variables with $\log (\mathrm{t})$, and added this new variable to the models, and then carried out these tests again (Box-Steffensmeier \& Jones, 2004: 132-136). The tests then show no signs of violations, and the results are very similar to the previous results. Hence, the original models are the ones presented in Table II. Furthermore, as an additional robustness check, I reestimated the model using a Weibull model, but the main results do not change. The results are also robust to alternative specifications such as clustering on conflict or country. In addition, since new parties may emerge I used an alternative dependent variable at the settlement level that captures post-settlement violence involving a signatory, non-signatory, or a new party. The findings were basically the same as those obtained when examining the overall peace duration.
} 
the log of GDP per capita. ${ }^{30}$ In sum, the various specifications show very similar results.

30 The data on GDP comes from the National Accounts Main Aggregates Database (United Nations, 2006). The type of political system was examined using data from the Polity IV data set, and the variable Polity ranges from -10 to +10 , where a higher score indicates a more democratic system. In order to control for a possible curvilinear relationship I also used the variable Polity-squared measured as the square of the Polity variable (Marshall \& Jaggers, 2003). 


\section{Conclusions}

This article set out to evaluate the claim in previous research that all-inclusive peace agreements are more likely to provide durable peace than partial agreements that leave out one or more rebel groups. Applying insights from bargaining theory it was proposed that the signatories should be able to anticipate the risk of violent challenges from outside actors, and hence, not affect their commitment to peace. Indeed, whereas excluded parties are likely to continue to fight, the signatories when signing a deal should already have considered such a scenario. The findings of this study accord with these theoretical expectations. The results showed that whether an agreement leaves out some actor does not affect whether the signatories stick to peace, but partial agreements can reduce the overall prospects for peace. Also in line with my argument, the study showed that outside actors are more likely to engage in post-settlement violence than the signatories. Importantly, the findings indicated that even if parties are excluded, and continue to fight, this does not affect the signatories' commitment to peace.

This study contributes to the scholarly literature in several ways. To begin with, by moving away from a characterization of civil war as involving only two parties and considering all rebel groups, this article contributes to the recent studies that in various ways attempt to take the empirical analysis one step further by disaggregating the study of civil war (e.g. Cunningham, 2006; Cunningham, Gleditsch \& Salehyan, 2007; Nilsson, 2006; Svensson, 2007). Furthermore, by taking into account all rebel groups it became possible to incorporate insights from case studies into the quantitative analysis, which facilitated an inquiry into the global patterns of inclusive peace agreements and durable peace. The finding that agreements that leave out some actor reduce the overall prospects for peace is in line with previous arguments, but to the extent that scholars on this topic have suggested that all-inclusive deals may affect the signatories' commitment to peace, the results here suggest otherwise (e.g. Rubin, 2002). The analysis also shed some light on our understanding of spoilers (e.g. Downs \& Stedman, 2002; Stedman, 1997). While spoiler attacks in various ways may influence a peace process, this study indicates that the exclusion of rebel groups from a settlement does not necessarily disrupt the peace among the signatories. This said, the exclusion of actors might play a role in specific cases, and in some instances result in intensification in violence. Hence, more research on this topic is needed. 
Furthermore, one implication of the argument that the warring parties are forward-looking is that some agreements never materialize if the parties deem the prospects for peace so bleak that they see no point in signing a deal at all. Therefore, a fruitful avenue for future research is to study this prior stage in the bargaining process. Such an inquiry may also serve to address the issue of whether a partial agreement is better than no agreement at all. Related to this, it would be interesting to study if there are certain types of groups that sign agreements and how this may influence the duration of peace.

The result that all-inclusive agreements do not affect the signatories' commitment to peace is perhaps less discouraging than it first appears. An important conclusion from the present study for policymakers is that it may be worthwhile for third parties to try to facilitate agreements even if it proves difficult or even impossible to bring all the parties to sign a deal. Indeed, the results demonstrate that even when excluded rebel groups engage in conflict, this does not affect the signatories' commitment to peace. Hence, this study shows that partial peace is possible. 
Table I. All-Inclusive Deals and the Risk of Post-Settlement Conflict: Settlement Level

\begin{tabular}{|c|c|c|}
\hline & Signatory Peace Duration & Overall Peace Duration \\
\hline & Model 1 & Model 2 \\
\hline \multirow[t]{2}{*}{ Exclusive-Multiple } & 0.750 & $1.843^{* *}$ \\
\hline & $(0.93)$ & $(2.25)$ \\
\hline \multirow[t]{2}{*}{ Two-Party Conflict } & 0.739 & 0.786 \\
\hline & $(0.81)$ & $(0.77)$ \\
\hline \multirow[t]{2}{*}{ Conflict Duration } & 0.986 & $1.028 *$ \\
\hline & $(0.49)$ & $(1.94)$ \\
\hline \multirow[t]{2}{*}{ Conflict Intensity } & $2.433 * * *$ & $1.679 * *$ \\
\hline & (2.69) & $(2.41)$ \\
\hline \multirow[t]{2}{*}{ Conflict Issue } & 1.959 & 1.120 \\
\hline & $(1.56)$ & $(0.45)$ \\
\hline \multirow[t]{2}{*}{ UN Peacekeeping } & 0.840 & 0.629 \\
\hline & $(0.43)$ & $(1.22)$ \\
\hline \multirow[t]{2}{*}{ Non-UN Peacekeeping } & 0.956 & 1.288 \\
\hline & $(0.12)$ & $(0.99)$ \\
\hline \multirow[t]{2}{*}{ Power Sharing } & $0.506^{*}$ & $0.515^{* *}$ \\
\hline & $(1.77)$ & $(2.31)$ \\
\hline Observations & 295 & 235 \\
\hline No. of Failures & 29 & 45 \\
\hline Log Likelihood & -113.281 & -184.757 \\
\hline
\end{tabular}

Note: A Cox proportional hazards model is employed. Hazard ratios rather than coefficients are reported, with robust z statistics (given in parentheses) clustered on conflict. *Statistically significant at the .10 level. ${ }^{* *}$ Statistically significant at the .05 level. ${ }^{* *}$ Statistically significant at the .01 level. Two-tailed tests are used. Stata 10.0 was used to generate the statistical results. 
Table II. Exclusion and the Risk of Post-Settlement Conflict: Dyadic Level

\begin{tabular}{|c|c|c|c|}
\hline & $\begin{array}{c}\text { Dyadic Peace } \\
\text { Duration }\end{array}$ & \multicolumn{2}{|c|}{ Dyadic Peace Duration (Signatories) } \\
\hline & Model 1 & Model 2 & Model 3 \\
\hline Excluded & $\begin{array}{l}2.001^{* * *} \\
(3.16)\end{array}$ & & \\
\hline Exclusive-Peace & & 1.139 & \\
\hline Agreement & & $(0.31)$ & \\
\hline Excluded-Fight & & & $\begin{array}{l}1.045 \\
(0.09)\end{array}$ \\
\hline Number of Parties & $\begin{array}{l}1.144 \\
(1.34)\end{array}$ & $\begin{array}{l}1.124 \\
(0.59)\end{array}$ & $\begin{array}{l}1.149 \\
(0.66)\end{array}$ \\
\hline Dyad-Conflict Duration & $\begin{array}{l}0.996 \\
(0.26)\end{array}$ & $\begin{array}{l}1.013 \\
(0.44)\end{array}$ & $\begin{array}{l}1.014 \\
(0.46)\end{array}$ \\
\hline Dyad-Conflict Intensity & $\begin{array}{l}1.300 \\
(1.06)\end{array}$ & $\begin{array}{l}1.027 \\
(0.07)\end{array}$ & $\begin{array}{l}1.048 \\
(0.13)\end{array}$ \\
\hline Conflict Issue & $\begin{array}{l}1.724^{* *} \\
(2.14)\end{array}$ & $\begin{array}{l}3.027^{* *} \\
(2.01)\end{array}$ & $\begin{array}{l}2.992^{* *} \\
(2.03)\end{array}$ \\
\hline UN Peacekeeping & $\begin{array}{l}0.599 \\
(1.55)\end{array}$ & $\begin{array}{l}1.000 \\
(0.00)\end{array}$ & $\begin{array}{l}0.988 \\
(0.03)\end{array}$ \\
\hline Non-UN Peacekeeping & $\begin{array}{l}2.050^{* * *} \\
(2.84)\end{array}$ & $\begin{array}{l}2.537 * * * \\
(2.77)\end{array}$ & $\begin{array}{l}2.533^{* * *} \\
(2.79)\end{array}$ \\
\hline Power Sharing & & $\begin{array}{l}0.566 \\
(1.33)\end{array}$ & $\begin{array}{l}0.567 \\
(1.34)\end{array}$ \\
\hline Observations & 477 & 376 & 376 \\
\hline No. of Failures & 62 & 33 & 33 \\
\hline Log Likelihood & -220.280 & -104.411 & -104.436 \\
\hline
\end{tabular}

Note: A Cox proportional hazards model is employed. Hazard ratios rather than coefficients are reported, with robust z statistics (given in parentheses) clustered on dyad. *Statistically significant at the .10 level. ${ }^{* *}$ Statistically significant at the .05 level. ${ }^{* *}$ Statistically significant at the .01 level. Two-tailed tests are used. Stata 10.0 was used to generate the statistical results. 


\section{References}

Ayres, R. William. 2006. 'No Peace At Any Price: The Effectiveness of Spoilers in Intrastate Conflicts'. Paper read at The Annual Meeting of the International Studies Association, 22-25 March, at San Diego, USA.

Box-Steffensmeier, Janet M. \& Bradford S. Jones, 2004. Event History Modeling: A Guide for Social Scientists. Cambridge: Cambridge University Press.

Cetinyan, Rupen, 2002. 'Ethnic Bargaining in the Shadow of Third-Party Intervention', International Organization 56(3): 645-677.

Cox, David R., 1972. 'Regression Models and Life Tables (with Discussion)', Journal of the Royal Statistical Society, Series B (Methodological) 34(2): 187-220.

Cunningham, David, 2006. 'Veto Players and Civil War Duration', American Journal of Political Science 50(4): 875-892.

Cunningham, David; Kristian Skrede Gleditsch \& Idean Salehyan, 2007. 'It Takes Two: A Dyadic Analysis of Civil War Duration and Outcome', Manuscript, cited January 2008,

(http://privatewww.essex.ac.uk/ ksg/papers/CGS_dyadic.pdf).

Downs, George \& Stephen John Stedman, 2002. 'Evaluation Issues in Peace Implementation', in John Stephen Stedman, Donald Rothchild \& Elizabeth M. Cousens, eds, Ending Civil Wars: The Implementation of Peace Agreements. Boulder \& London: Lynne Rienner Publishers (43-69).

Doyle, Michael W. \& Nicholas Sambanis, 2000. 'International Peacebuilding: A Theoretical and Quantitative Analysis', American Political Science Review 94(4): 779-801.

Fearon, James D., 1995. 'Rationalist Explanations for War', International Organization 49(3): 379-414.

Filson, Darren \& Suzanne Werner, 2002. 'A Bargaining Model of War and Peace: Anticipating the Onset, Duration, and Outcome of War', American Journal of Political Science 46(4): 819-838.

Fortna, Virginia Page, 2003. 'Inside and Out: Peacekeeping and the Duration of Peace after Civil and Interstate Wars', International Studies Review 5(4): 97-114.

Fortna, Virginia Page, 2004. 'Does Peacekeeping Keep Peace? International Intervention and the Duration of Peace after Civil War', International Studies Quarterly 48(2): 269-292. 
Hampson, Fen Osler, 1996. Nurturing Peace: Why Peace Settlements Succeed or Fail. Washington, D.C.: United States Institute of Peace Press.

Harbom, Lotta; Stina Högbladh \& Peter Wallensteen, 2006. 'Armed Conflict and Peace Agreements', Journal of Peace Research 43(5): 617-631.

Hartzell, Caroline A. \& Matthew Hoddie, 2003. 'Institutionalizing Peace: Power Sharing and Post-Civil War Conflict Management', American Journal of Political Science 47(2): 318-332.

Hartzell, Caroline A.; Matthew Hoddie \& Donald Rothchild, 2001. 'Stabilizing the Peace After Civil War: An Investigation of Some Key Variables', International Organization 55(1): 183-208.

Heldt, Birger \& Peter Wallensteen, 2006. Peacekeeping Operations: Global Patterns of Intervention and Success, 1948-2004, Second Edition. Sandöverken: Folke Bernadotte Academy Publications.

Hoddie, Matthew \& Caroline A. Hartzell, 2003. 'Civil War Settlements and the Implementation of Military Power-Sharing Arrangements', Journal of Peace Research 40(3): 303-320.

Jarstad, Anna \& Desirée Nilsson, 2007. 'From Words to Deeds: The Implementation of Power-Sharing Pacts in Peace Accords', Manuscript, Department of Peace and Conflict Research, Uppsala University.

Lake, David A. \& Robert Powell, 1999. 'International Relations: A Strategic-Choice Approach', in David A. Lake \& Robert Powell, eds, Strategic Choice and International Relations. Princeton: Princeton University Press (3-38).

Licklider, Roy, 2001. 'Obstacles to Peace Settlements', in Chester A. Crocker, Fen Osler Hampson \& Pamela Aall, eds, Turbulent Peace: The Challenges of Managing International Conflict. Washington D.C.: United States Institute of Peace Press (697-718).

Marshall, Monty G. \& Keith Jaggers, 2003. Polity IV Project, Political Regime Characteristics and Transitions, 1800-2003, cited 1 February 2005, (http://www.cidcm.umd.edu/inscr/polity/).

Newman, Edward \& Oliver Richmond, 2006. Challenges to Peacebuilding: Managing Spoilers During Conflict Resolution. Tokyo: United Nations University Press. 
Nilsson, Desirée, 2006. In the Shadow of Settlement: Multiple Rebel Groups and Precarious Peace. Uppsala: Department of Peace and Conflict Research, Uppsala University.

Nilsson, Desirée; Isak Svensson \& Ralph Sundberg, 2006. 'The Terms of Peace Agreements Data (TOPAD) Codebook', Department of Peace and Conflict Research, Uppsala University.

Ohlson, Thomas \& Mimmi Söderberg. 2002. 'From Intra-State War To Democratic Peace in Weak States'. In Uppsala Peace Research Papers: Department of Peace and Conflict Research, Uppsala University.

Rubin, Jeffrey Z., 2002. 'The Actors in Negotiation', in Victor A. Kremenyuk, eds, International Negotiation: Analysis, Approaches, Issues, Second Edition. San Francisco: Jossey-Bass (97-109).

Sollenberg, Margareta, 2002. 'The Uppsala Conflict Data Project: A Background Note for the Internet Database', Department of Peace and Conflict Research, Uppsala University.

StataCorp, 2007. Stata Statistical Software: Release 10. College Station, TX: StataCorp LP.

Stedman, Stephen John, 1997. 'Spoiler Problems in Peace Processes', International Security 22(2): 5-53.

Svensson, Isak, 2007. 'Bias, Bargaining, and Peace Brokers: How Rebels Commit to Peace', Journal of Peace Research 44(2): 177-194.

Tomz, Michael; Jason Wittenberg \& Gary King, 2001. CLARIFY: Software for Interpreting and Presenting Statistical Results. Version 2.0 Cambridge, MA: Harvard University, June 1., cited September 2007, (http://gking.harvard.edu).

UCDP, The Uppsala Conflict Data Program, 2006. cited June 2006, (http://www.ucdp.uu.se).

United Nations, 2006. The National Accounts Main Aggregates Database, cited January 2006, (http://unstats.un.org/unsd/snaama/Introduction.asp).

Wallensteen, Peter, 2002. Understanding Conflict Resolution: War, Peace and the Global System. London: Sage Publications.

Walter, Barbara F., 1999. 'Designing Transitions from Civil War: Demobilization, Democratization and Commitments to Peace', International Security 24(1): 127-155. 
Walter, Barbara F., 2002a. Civil War Resolution Data Set Codebook, cited December 2005, (http://www-irps.ucsd.edu/academics/f-walter.php).

Walter, Barbara F., 2002b. Committing to Peace: The Successful Settlement of Civil Wars. Princeton and Oxford: Princeton University Press.

Walter, Barbara F., 2006. 'Building Reputation: Why Governments Fight Some Separatists but Not Others', American Journal of Political Science 50(2): 313330.

Werner, Suzanne \& Amy Yuen, 2005. 'Making and Keeping Peace', International Organization 59(2): 261-292.

Zahar, Marie-Joëlle, 2003. 'Reframing the Spoiler Debate in Peace Processes', in John Darby \& Roger Mac Ginty, eds, Contemporary Peacemaking: Conflict, Violence and Peace Processes. London: Palgrave Macmillan (114-124).

Zartman, I. William, ed., 1995. Elusive Peace: Negotiating an End to Civil Wars. Washington D.C.: The Brookings Institution. 